\title{
Pengaruh Video Learning Multimedia terhadap Pengetahaun, Sikap dan Perilaku Menstrual Hygiene pada Remaja Putri
}

\author{
Effects of Multimedia Learning Videos on Changes In Hygiene \\ Menstruation Knowledge, Attitudes and Behavior In Young Women
}

\author{
Andi Basniati ${ }^{1}$, Sri Ramadhany ${ }^{2}$, Muhammad Tamar $^{3}$, Nurhikmah ${ }^{4}$, Fanni Astuti ${ }^{5}$ \\ ${ }^{1,3}$ Magister Kebidanan Sekolah Pasca Sarjana Universitas Hasanuddin, Makassar \\ ${ }^{2}$ Fakultas Kedokteran Universitas Hasanuddin, Makassar \\ ${ }^{4}$ Akademi kebidanan Mayapada Gading Persada \\ ${ }^{5}$ Sekolah Tinggi Ilmu Kesehatan Salewangang Maros \\ ${ }^{1}$ Email :andibasniati@pasca.unhas.ac.id
}

\begin{abstract}
ABSTRAK
Berdasarkan hasil survey yang dilakukan oleh Departemen Kesehatan yang dimuat dalam (SKDI, 2012). Menunjukkan bahwa tingkat pengetahuan dan pemahaman remaja tentang kesehatan reproduksi masih sangat rendah. Konsekuensi dari rendahnya pengetahuan dan pemahaman remaja terhadap kesehatan reproduksi adalah mudahnya remaja mengalami masalah yang berhubungan dengan kesehatan reproduksi. Penelitian ini bertujuan untuk menganalisis pengaruh video learning multimedia terhadap perubahan sikap dan perilaku menstrual hygiene pada remaja putri. Jenis penelitian ini merupakan quasy eksperimen (pre-post test design). Penelitian dilakukan di pondok pesantren ummul mukminin (kelompok intervensi) dan pondok pesantren darul arqam muhammadiyah gombara (kelompok kontrol) pada januari 2020. Sampel dalam penelitian ini sebanyak 62 sampel, 31 sampel kelompok kontrol dan 31 kelompok intervensi (Video Learning Multimedia) yang dipilih berdasarkan tekhnik purposive sampling. Analisis data dengan uji Homogeneity of variancedan uji Wilcoxon. Hasil uji statistik menunjukkan bahwa terdapat pengaruh video learning multimedia terhadap perubahan pengetahuan, sikap dan perilaku menstrual hygiene pada remaja putri.
\end{abstract}

Kata kunci: Video Learning Multimedia, Remaja, Menstrual Hygiene, Pengetahuan, Sikap, Perilaku.

\begin{abstract}
Based on the results of a survey conducted by the Ministry of Health which is published in (SKDI, 2012). Showed that the level of knowledge and understanding of adolescents about reproductive health was still very low. The consequence of the low knowledge and understanding of adolescents on reproductive health is that it is easy for adolescents to experience problems related to reproductive health. This study aims to analyze the effect of multimedia video learning on changes in attitude and behavior of menstrual hygiene in young women. This type of research was a quasy experiment (pre-post test design). The research was conducted at the Ummul Mukminin Islamic boarding school (intervention group) and the Darul Arqam Muhammadiyah Gombara Islamic boarding school (control group) in January 2020. The sample in this study was 62 samples, 31 samples from the control group and 31 intervention groups (Video Learning Multimedia) which were selected based on purposive sampling technique. Data analysis using Homogeneity of Variance and Wilcoxon test. The results of statistical tests showed that there was an effect of multimedia video learning on changes in knowledge, attitudes and behavior of menstrual hygiene in young women.
\end{abstract}

Keywords: Multimedia Video Learning, Teenagers, Menstrual Hygiene, Knowledge, Attitudes, Behavior. 


\section{PENDAHULUAN}

Remaja merupakan salah satu periode dari perkembangan manusia dimana pada masa ini terjadi suatu perubahan baik bilogis, psikologis maupun sosial. (Estiwidiani et.al 2009 \& Puspitaningrum et.al 2017). Remaja adalah generasi muda yang merupakan aset yang sangat penting karena remaja memiliki tanggung jawab kelangsungan hidup bangsa.

Masa remaja (adolescence) merupakan masa transisi atau peralihan dari masa anak-anak menuju dewasa yang ditandai adanya perubahan fisik, psikis dan psikososial (Nuraini, 2012). Periode ini diakui sebagai periode khusus siklus kehidupan seorang gadis yang ditandai dengan Menarche. Menarche merupakan tonggak penting biologi dalam kehidupan seorang wanita karena menandai awal dari fase reproduksi hidupnya. (Estiwidani etal 2009 \& Ranjabir,2018).

Di Indonesia badan pusat statistic Indonesia (BPS) mencatat jumlah remaja hingga akhir 2018 sebanyak 45 juta jiwa. Remaja yang merupakan bagian dari penduduk Indonesia jumlahnya mencapai $37 \%$ dari total penduduk Indonesia 237,6 juta orang
(Aden, 2010. \& (Mamilla \& Goundla, 2019).

Menstruasi merupakan tanda permulaan pubertas pada remaja. Menstruasi pertama pada remaja biasa terjadi dalam rentang usia 10-16 tahun atau pada masa awal remaja di tengah masa pubertas sebelum memasuki masa reproduksi. Menstruasi adalah perdarahan periodik dari uterus yang dimulai sekitar 14 hari setelah ovulasi secara berkala akibat terlepasnya lapisan endometrium uterus (Bobak, 2004 dalam Felicia et al 2015).

Menstrual hygiene dapat didefenisikan sebagai menjaga kebersihan selama menstruasi dengan penggunaan material untuk menyerap atau mengumpulkan darah menstruasi, dan bahan yang digunakan dapat diganti sesering mungkin sesuai kebutuhan saat mengalami menstruasi, juga termasuk penggunaan sabun, air untuk mencuci area kewanitaan dan bagian tubuh lainnya dan tempat mengganti bahan penyerap darah menstruasi (pembalut). (USAID, 2013 dan UKAID 2014).

Kurangnya kesadaran Menstrual Hygiene dan perawatan selama menstruasi yang disebabkan oleh kurangnya pengetahuan,sikap dan peilaku yang berkaitan dengan 
menstruasi dan kebersihan menstruasi dapat menimbulkan masalah bagi remaja. Sebuah studi yang dilakukan di Nagpur melaporkan bahwa hanya $36.95 \%$ dari gadis-gadis itu menyadari menstruasi sebelum menarche. Lebih dari tiga dari 10 gadis tidak menyadari tentang penyebab dan sumber perdarahan sedangkan mayoritas dari mereka bahkan mengetahui tentang penggunaan pembalut. (Anusree et al., 2014), dalam penelitiannya juga menggambarkan bahwa ada perawatan yang tidak tepat dan tidak memadai dalam praktek higienis saat menstruasi kalangan remaja perempuan.

Menstrual hygiene yang tidak adekuat akan merugikan remaja putri. Penelitian yang dilakukan oleh Unicef di Indonesia pada tahun 2015 di empat provinsi menunjukkan bahwa satu dari tujuh remaja putri tidak masuk sekolah tiap bulannya selama 1-3 hari dikarenakan menstruasi yang dialaminya, terkait dengan kurangnya informasi mengenai menstrual higiene, kurangnya fasilitas sekolah yang tidak memadai untuk menunjang kebersihan diri remaja putri selama menstruasi. Informasi yang buruk mengenai menstrual hygiene menyebabkan meningkatnya resiko infeksi, rasa ketidaknyamanan dan iritasi pada remaja putri.(Unicef, 2015).

Hasil studi pendahuluan yang dilakukan peneliti di pondok pesantren ummul mukminin di dapatkan data dari pihak yayasan dan kepala sekolah bahwa di pondok pesantren ummul mukminin belum pernah diadakan penelitian dan pendidikan kesehatan reproduksi remaja terkait menstrual hygiene. Data yang didapatkan dari 10 remaja putri yang sudah menstruasi bahwa mereka belum pernah mendapatkan pendidikan dan informasi tentang menstrual hygiene. Sumber informasi tentang menstrual hygiene yang mereka dapatkan bermacammacam, 7 dari mereka menjawab sumber informasi berasal dari teman dan yang lainnya menjawab dari orang tua, guru dan media online. Mereka bahkan tidak tau berapa kali sebaiknya mengganti pembalut saat menstruasi dan bagaimana cara membersihkan pembalut bekas pakai sebelum di buang ke tempat sampah. Hal ini dimungkinkan karena di pondok pesantren, penyampaian materi tentang menstruasi pada siswa hanya melalui mata pelajaran ipa.

Video Learning Multimedia adalah media pembelajaran yang 
menggunakan video atau tampilan bergerak, Multimedia adalah penyampaian informasi menggunakan gabungan dari teks, grafik, suara, video, animasi. Teknologi multimedia sangat efisien dalam segi waktu bagi pendidik karena tanpa harus menyuruh peserta didik mencatat materi cukup dengan mengcopy file yang telah disampaikan. Dengan menggunakan teknologi media pembelajaran akan meningkatkan kemampuan belajar sebesar $50 \%$, dari pada tanpa mempergunakan media

Berdasarkan uraian tersebut peneliti tertarik dan ingin melakukan penelitian dengan judul Pengaruh Video Learning Multimedia Terhadap Perubahan Pengetahuan, Sikap dan Perilku Menstrual Hygiene pada Remaja Putri

\section{METODE PENELITIAN}

Jenis Penelitian yang digunakan adalah penelitian Quasy Eksperimen dengan noevaqualent control group pre-post design. Responden dibagi dua kelompok yakni kelompok kontrol dengan metode ceramah dan kelompok intervensi dengan Video Learning Multimedia. Pre-test dan post-test dilakukan masing satu kali baik pada kelompok kontrol maupun pada kelompok intervensi. Sampel dalam penelitian ini adalah siswa kelas VII Mts sebanyak 62 sampel, 31 sampel pada kelompok kontrol dan 31 sampel pada kelompok intervensi. Dengan kriteria inklusi. Remaja putri kelas VII, usia 10-13 tahun, bersedia jadi responden, sehat jasmani dan rohani, responden sudah menstruasi, Responden tereksklusi apabila siswa tidak hadir pada saat penelitiain berlangsung.

Penelitian ini dilakukan dengan menggunakan menggunakan metode pembelajaran yaitu Video learning multimedia. Instrumen yang digunakan dalam penelitian ini adalah kuesioner.

Analisis dalam penelitian ini menggunakan uji statistik. Penelitian ini menggunakan Uji homogeneity of variance untuk melihat sebaran data pada kedua kelompok dan Uji Wilcoxon untuk melihat signifikansi perubahan dalam satu kelompok sebelum dan sesudah perlakuan.

\section{HASIL DAN PEMBAHASAN}

Sebanyak 31 responden yang diberikan Video learning multimedia (Kelompok intervensi) dan 31 responden yang diberikan Ceramah (kelompok control). 
Tabel 1. Distribusi Karakteristik Responden $(\mathrm{N}=62)$

\begin{tabular}{|c|c|c|c|}
\hline Karakteristik & $\begin{array}{c}\text { Kelompok } \\
\text { Kontrol } \\
\text { f }(\%)\end{array}$ & $\begin{array}{c}\text { Kelompok } \\
\text { Intervensi } \\
\mathbf{f}(\%)\end{array}$ & $\begin{array}{c}\text { P- } \\
\text { value }\end{array}$ \\
\hline \multicolumn{4}{|l|}{ Umur } \\
\hline 11 tahun & $1(50)$ & $1(50)$ & \\
\hline 12 tahun & $29(52.7)$ & $26(47.3)$ & 0.3 .75 \\
\hline 13 tahun & $1(20.0)$ & $4(80.0)$ & \\
\hline \multicolumn{4}{|l|}{ Usia menarche } \\
\hline 10 tahun & $12(75.0)$ & $4(25.0)$ & \\
\hline 11 tahun & $9(31.0)$ & $20(69.0)$ & 0.013 \\
\hline 12 tahun & $10(58.8)$ & 7 (41.2) & \\
\hline \multicolumn{4}{|l|}{$\begin{array}{l}\text { Lama } \\
\text { menstruasi }\end{array}$} \\
\hline 4 hari & $2(66.7)$ & $1(33.3)$ & \\
\hline 5 hari & $4(44.4)$ & $5(55.6)$ & \\
\hline 6 hari & $0(0.0)$ & $7(100)$ & 0.010 \\
\hline 7 hari & $12(44.4)$ & 15 (55.6) & \\
\hline 8 Hari & $4(57.1)$ & $3(42.9)$ & \\
\hline 9 hari & $7(100)$ & $0(0.0)$ & \\
\hline 10 hari & $2(100)$ & $0(0.0)$ & \\
\hline
\end{tabular}

*Uji homogeneity of variance

Tabel 1 diatas menunjukkan karakteristik yang dominan sama atau homogen. Berdasarkan umur, cenderung sama yaitu pada kelompok yaitu umur 12 tahun, kelompok kontrol sebanyak 29 responden ( 52.7\%) dan pada kelompok intervensi $26(47.3 \%)$ dengan $p$-value $<0.375$ lebih kecil dari $(<0.05)$. pada karakteristik usia menarche pada kelompok kontrol, usia menarche lebih banyak terjadi pada usia 10 tahun sebanyak 12 responden (75.0\%), sedangkan pada kelompok intervensi usia menarche dominan terjadi pada usia 11 tahun sebanyak 20 responden (69.0\%) dengan p-value 0.013 lebih kecil dari $(<0.05)$. Jika dilihat dari lama menstruasi pada kelompok kontrol maupun kelompok intervensi lama menstruasi dominan berlangsung 7 hari, pada kelompok kontrol sebanyak 12 responden 12 (44.4\%) dan pada kelompok intervensi sebanyak 15 responden $(55.6 \%)$ dengan p-value 0.010 lebih kecil dari $(<0.05)$.

Tabel 2. Perbedaan pengetahuan, sikap dan perilaku pre dan post perlakuan pada kelompok kontrol dan perlakuan (n:62)

\begin{tabular}{cccc}
\hline Variabel & \multicolumn{2}{c}{ Mean Rank Kelompok } & $\begin{array}{c}\text { P- } \\
\text { value }\end{array}$ \\
\cline { 2 - 3 } Kontrol & Intervensi & Z & $<0.001$ \\
Pengetahuan & & & \\
Pre post & 17.53 & 45.47 & \\
Post test & 16.95 & 46.05 & $<0.001$ \\
Sikap & & & \\
Pre post & 19.81 & 44.84 & \\
Post test & 16.95 & 46.05 & $<0.001$ \\
Perilaku & & & \\
Pre post & 20.87 & 41.29 & \\
Post test & 19.87 & 43.50 & \\
\hline
\end{tabular}

*Uji mann-whitney

Tabel 2 diatas menunjukkan bahwa variabel pengetahuan pada kedua kelompok terdapat perbedaan pengetahuan yang signifikan baik pada pre-test maupun post-test dengan $\mathrm{p}$ value $<0.001$ lebih kecil dari $(<0.005)$.

Berdasarkan sikap , hasil uji statistik menunjukkan perdedaan yang signifikan antara keedua kelompok baik pre-test maupun post-test, dimana sikap 
pre-test kelompok kontrol 19.81, kelompok intervensi 44.84 sedangkan sikap post-test kelomppok kontrol 16.95, kelompok intervensi 46.05 dengan p-value $<0.001$ lebih kecil dari $(<0.005)$.

Pada perilaku menunjukkan perbedaan yang sangat signifikan nila pre-test dan post-test antara kedua kelompok. Dimana perilaku pre-test kelompok kontrol 20.87 dan pretest kelompok intervensi 41.29, sedangkan perilaku post-test kelompok kontrol 19.50 dan perilaku posttest kelompok intervensi 43.50 dengan $p$-value $<0.001$ lebiih kecil dari $(<0.005)$.

Tabel 3. Perbedaan pengetahuan, sikap dan perilaku pre dan post perlakuan pada kelompok control dan perlakuan $(\mathrm{N}: 62)$

\begin{tabular}{clcc}
\hline \multicolumn{1}{c}{ Variabel } & & \multicolumn{2}{c}{ Kelompok } \\
& & Kontrol & Intervensi \\
\hline \multirow{2}{*}{ Pengetahuan Pre test } & p-value* & $<0.001$ & $<0.001$ \\
$\&$ & Menurun & 3 & 0 \\
Pengetahuan Post test & Meningkat & 21 & 21 \\
& Menetap & 7 & 10 \\
Sikap Pre test & p-value* & 0.021 & $<0.001$ \\
$\&$ & Menurun & 3 & 2 \\
Sikap Post test & Meningkat & 17 & 25 \\
& Menetap & 11 & 4 \\
Perilaku Pre test & p-value* & 0.012 & $<0.001$ \\
$\&$ & Menurun & 4 & 2 \\
Perilaku Post test & Meningkat & 14 & 28 \\
*Uji Wilcoxon & Menetap & 13 & 1 \\
\hline
\end{tabular}

*Uji Wilcoxon

Hasil uji statistik sikap pre-post

Hasil uji statistik pengetahuan pre-post test menunjukkan pada kelompok kontrol maupun kelompok intervensi terdapat peningkatan yang signifikan sebelum dan sesudah diberikan ceramah $<0.001$ lebih kecil dari $(\mathrm{p}<0.05)$. ditunjang oleh distribusi data yang memperlihatkan peningkatan pengetahuan sebelum dan sesudah test baik kelompok kontrol maupun pada kelompok intervensi. test menunjukkan pada kelompok kontrol 0.021 lebih kecil dari $(p<0.05)$ dan kelompok intervensi <0.001 lebih kecil dari $(\mathrm{p}<0.05)$.

Hasil uji statistic perilaku pre-post test menunjukkan pada kelompok kontrol 0.012 lebih kecil dari $(\mathrm{p}<0.05)$ dan kelompok intervensi <0.001 lebih kecil dari $(\mathrm{p}<0.05)$.hal ini ditunjang dengan peningkatan pre-post test pada masingmasing kelompok. 
Pada penelitian ini didapatkan hasil yang menunjukkan pengaruh video learning terhadap perubahan pengetahuan sikap dan perilaku menstrual hygiene remaja putri. Pengaruh video learning terhadap perubahan pengetahuan didapatkan nilai p-value 0.001 lebih kecil dari $(<0.05)$ dimana terdapat peningkatan sebelum dan sesudah diberikan intervensi video learning multimedia, dimana pada pretest responden berpengetahuan baik sebanyak 30 responden $(76.9 \%)$ dan pada post-test meningkat jadi 31 responden $(100 \%)$.

Pada kategori sikap menununjukkan ada pengaruh sebelum dan sesudah diberikan intervensi video learning multimedia dengan nilai $\mathrm{p}$ value 0.001 lebih kecil dari $(<0.05)$ dimana pada pre-test responden dengan sikap baik sebanyak 30 responden (73.2\%) dan pada post-test sebanyak 31 responden $(100 \%)$.

Pada kategori perilaku menununjukkan ada pengaruh sebelum dan sesudah diberikan intervensi video learning multimedia dengan nilai $\mathrm{p}$ value 0.001 lebih kecil dari $(<0.05)$ dimana pada pre-test responden dengan sikap baik sebanyak 27 responden
(75.6\%) dan pada post-test sebanyak 27 responden $(81.8 \%)$.

1. Analisis perbedaan pengetahuan, sikap dan perilaku pre-test kelompok kontrol dan pre-test kelompok intervensi serta post-test kelompok kontrol dan post-test kelompok intervensi.

Hasil uji statistik pengetahuan tentang menstrual hygiene menunjukkan perbedaan yang signifikan antara kelompok kontrol dan kelompok intervensi. Hal ini bisa dilihat pada variabel pengetahuan kelompok kontrol pre-test $17.53 \%$ pada kelompok intervensi pengetahuan pre-test 45.47, sedangkan pengetahuan pada posttest kelompok kontrol $16.95 \%$ pada kelompok intervensi $46.05 \%$ dengan nilai p-value $<0.001$ lebih kecil dari $(<0.05)$ yang berarti menunjukkan ada pengaruh video learning multimedia terhadap perubahan pengetahuan remaja putri setelah dilakukan intervensi.

$$
\text { Pada penelitian yang }
$$
dilakukan oleh (Angraeni,O,.2016) yang memberikan pendidikan kesehatan dengan metode video learning pada ibu berhasil meningkatkan pengetahuan pada 
siswa SMK tentang kesehatan reproduksi untuk mencegah keputihan. Dengan demikian meskipun memiliki variabel dan tingkatan responden yang berbeda, video learning multimedia merupakan media yang interaktif, menarik dan baik untuk memperoleh dan menyampaikan informasi bagi respond untuk meningktakan pengetahuan tentang menstrual hygiene. Hasil uji statistik sikap tentang menstrual hygiene Menunjukkan perbedaan yang signifikan antara kelompok kontrol dan kelompok intervensi. Hal ini bisa dilihat pada variabel sikap kelompok kontrol pre-test $19.81 \%$ pada kelompok intervensi sikap pre-test $44.84 \%$, sedangkan sikap pada posttest kelompok kontrol $16.95 \%$ pada kelompok intervensi $46.05 \%$ dengan nilai p-value $<0.001$ lebih kecil dari $(<0.05)$ yang berarti menunjukkan ada pengaruh video learning multimedia terhadap perubahan sikap remaja putri setelah dilakukan intervensi.

Hal ini sesuai dengan penelitian (Mamilia, 2019 dan Meinarisa,2019) menunjukkan bahwa ada pengaruh $\mathrm{PMH}$ (pendidikan kesehatan menstrual hygiene) terhadap perubahan sikap remaja putri karena penyampaian informasi yang lebih menarik dan mudah diterima oleh remaja, desertai dengan demonstrasi video Sehingga seseorang akan dapat mengingat $70 \%$ dibandingkan dengan mendengar yang hanya $30 \%$. Oleh karena itu video learing multimedia sangat membantu dalam proses pembelajaran sehingga dapat meningkatkan pengetahuan dan sikap responden.

$\begin{array}{clc}\text { Hasil } & \text { uji statistik } & \text { perilaku } \\ \text { tentang } & \text { menstrual } & \text { hygiene }\end{array}$
menunjukkan perbedaan yang signifikan antara kelompok kontrol dan kelompok intervensi. Hal ini bisa dilihat pada variabel perilaku kelompok kontrol pre-test $20.87 \%$ pada kelompok intervensi perilaku pre-test $41.29 \%$, sedangkan perilaku pada post-test kelompok kontrol $19.50 \%$ pada kelompok intervensi $43.50 \%$ dengan nilai $\mathrm{p}$-value $<0.001$ lebih kecil dari $(<0.05)$ yang berarti menunjukkan ada pengaruh video learning multimedia terhadap perubahan perilaku remaja putri setelah dilakukan intervensi.Hal ini sesuai dengan penelitian (Puspita 
Sari, 2015) menunjukkan bahwa adanya pengaruh pendidikan kesehatan tentang menstrual hygiene pada remaja putri, metode pendidikan kesehatan merupakan metode yang tepat untuk memberikan informasi kepada remaja. Karenanya video learning multimedia dianggap metode pendidikan yang lengkap dari segi isi,konten yang dapat menarik minat siswa untuk menonton atau mengikuti pelajaran.

2. Analisis perbedaan pengetahuan, sikap dan perilaku pre-post test pada kelompok kontrol dan kelompok intervensi.

Hasil uji statistik pengetahuan uji pengetahuan sebelum dan sesudah diberikan perlakuan pada kelompok kontrol dan kelompok inteervensi didaptkan p-value <0.001 lebih kecil dari (<0.05). Pada variabel sikap kelompok kontrol di dapatkan pvalue 0.021 lebih kecil dari $(<0.05)$, dan kelompok intervensi di dapatkan p-value $<0.001$ lebih kecil dari $(<0.05)$. sedangkan pada variabel perilaku, kelompok kontrol didaptkan p-value 0.012 lebih kecil dari $(<0.05)$, dan pada kelompok intervensi didaptkan p-value $<0.001(<0.05)$.

Hal ini sesuai dengan harapan peneliti bahwa ada perubahan pengetahuan, sikap dan perilaku setelah diberikan intervensi video learning multimedia.

Hal ini sejalan dengan teori (Munir,2012) menyatakan bahwa animasi adalah suatu kegiatan menghidupkan atau menggerakkan benda mati (gambar) menjadi seolaholah hidep, karena animasi mampu menjelaskan suatu konsep atau proses yang sulit dijelaskan dengan media lain sehingga menimbulkan motivasi siswa untuk ikut berperan aktif dalam proses pembelajaran. Hal tersebut sesuai dengan pemaparan (Azhar A,2011) yang menyatakan bahwa media pembelajaran dapat menarik perhatian siswa, sehingga menimbulkan motivasi belajar dari dalam diri siswa.

Hasil penelitian (Handayani, L, 2017) menyatakan bahwa ada peningkatan pengetahuan tentang hiv/aids sebelum dan sesudah diberikan pendidikan kesehatan dengan media video. Hal yang sama juga dijelaskan oleh (Robinson 2009, dalam (Ediyanti,L, 2014) 
menyatakan bahwa terdapat pengaruh pendidikan kesehatan dengan media video terhadap pengetahuan, sikap dan perilaku tentang personal hygiene pada anak panti asuhan.

Beberapa pendapat diatas sejalan dengan penelitian (Luluk, E , 2014), yang menyatakan dalam penelitiannya bahwa pendidikan kesehatan dengan menggunakan media video mempunyai dampak dan berpengaruh terhadap perubahan sikap dan perilaku seseorang

Menurut asumsi peneliti penggunaan media pembelajaran berupa video learning dapat merubah pengetahuan, sikap dan perilaku menstrual hygiene remaja putri, karena media video dianggap lebih menarik dan lebih efisien dalam proses pembelajaran. Media video pembelajaran juga dianggap lebih lengkap dari segi isi, konten dan tampilan yang dapat menarik minat siswa untuk menonton atau mengikuti pelajaran.

Hasil penelitian ini sejalan dengan (Handayani, L, 2017) yang menyatakan bahwa ada peningkatan pengetahuan tentang hiv/aids sebelum dan sesudah diberikan pendidikan kesehatan dengan media video. Hal ini juga sejalan dengan penelitian (Robinson 2009, dalam (Ediyanti,L, 2014) menyatakan bahwa terdapat pengaruh pendidikan kesehatan dengan media video terhadap pengetahuan, sikap dan perilaku tentang personal hygiene pada anak panti asuhan.

Menurut asumsi peneliti penggunaan media pembelajaran berupa video learning dapat merubah pengetahuan, sikap dan perilaku menstrual hygiene remaja putri karena dianggap lebih efisien dan lebih modern serta interaktif untuk pembelajaran serta media pembelajaran yang lebih lengkap dari segi isi,konten yang dapat menarik minat siswa untuk menonton atau mengikuti pelajaran.

\section{SIMPULAN DAN SARAN}

Kesimpulan hasil penelitian adalah sebagai berikut:

1. Adanya perbedaan yang bermakna nilai pengetahuan, sikap dan perilaku menstrual hygiene responden pada kelompok intervensi sebelum dan sesudah diberikan intervensi.

2. Ada pengaruh video learning multimedia terhadap perubahan 
pengetahuan, sikap dan perilaku menstrual hygiene pada remaja putri di Pondok pesantren ummul mukminin kota Makassar sebagai kelompok intervensi.

Saran Untuk peneliti selanjutnya diharapkan untuk memodifikasi variabel video learning multimedia guna lebih meningkatkan perubahan pengetahuan, sikap dan perilaku menstrual hygiene. Durasi waktu penelitian yang lebih lama serta durasi pemberian intervensi di tambah agar tujuan penelitian dapat tercapai dengan baik.

\section{DAFTAR PUSTAKA}

Anusree, P. C., Roy, A., Sara, A. B., Vcm, F., Babu, G. P., \& Tamrakar, A. (2014). Knowledge Regarding Menstrual Hygiene among Adolescent Girls in selected school, Mangalore with a View to Develop an Information Booklet, 3(1), 55-60. https://doi.org/e-ISSN: 23201959.p- ISSN: 2320-1940.

Angraeni, O. (2016). Hubungan status gizi dengan siklus menstruasi pada remaja putri di PSIK FK UNSRAT Manado. E-Journal Keperawatan, Vol 3, No 1.Manado.

Arsyad, Azhar. (2016). Media Pembelajaran. Jakarta: Raja Grafindo Persada.

Azwar S. (2013). Sikap Manusia: Teori dan Pengukurannya. Yogyakarta:
Pustaka Pelajar.

Dhuangga, W.P., dan Misrawati. (2012). Efektifitas pendidikan kesehatan tentang hygiene kewanitaan terhadap pengetahuan dan sikap remaja putri dalam menangani keputihan. Journal Ners Indonesia,2 (2) ; 1-5.

Edyati, L. (2014). Pengaruh penyuluhan kesehatan dengan media video terhadap pengetahuan dan sikap personal hygiene siswa SD Negeri 1 Kepek Pengasih Kulon Progo. Yogyakarta.

Eswi, A., Helal, H., \& Elarousy, W. (2012). Menstrual Attitude and Knowledge among Egyptian Female Adolescents. Journal of American Science, 8(6), 555-565. https://doi.org/1545-1003

Handayani, L. (2017) Pengaruh Pendidikan Kesehatan dengan Media Video terhadap Tingkat Pengetahuan tentang Pencegahan HIV/AIDS di SMA Negeri 1 Parigi Kabupaten Pangandaran. Yogyakarta: Skripsi. Universitas Aisiyah.

Luluk, dan Erik. (2014). Pengaruh Penyuluhan Kesehatan Dengan Media Video Terhadap Pengetahuan Dan Sikap Personal Hygiene Siswa SD Negeri 1 Kepek Pengasih Kulon Progo. Program studi ilmu keperawatan sekolah tinggi ilmu kesehatan aisyiyah yogyakarta.

Mamilla, S., \& Goundla, S. (2019). Knowledge about menstrual hygiene, sexual health, and contraception in educated late adolescent age girls, 610-613. 
https://doi.org/10.4103/jfmpc.jfm pc

Meinarisa. (2019). Pengaruh Pendidikan Kesehatan Menstrual Hygiene (PMH) Terhadap Sikap Remaja Putri dalam Menjaga Kebersihan Diri Selama Menstruasi. Jurnal Endurance, 4(1), 141-149.

Munir. (2013). Multimedia konsep dan aplikasi dalam pendidikan. Bandung: Alfabeta.

Nuraini. (2012). Hubungan antara tingkat stres dengan siklus menstuasi pada mahasiswi asrama Universitas Andalas.

Purwoastuti, E., \& Walyani, Siwi, E. (2015). Perilaku dan Softskill Kesehatan. Yogyakarta: PT Pustaka Baru.

Putri, N. A., \& Setianingsih, A. (2016). Hubungan Pengetahuan dan Sikap Terhadap Perilaku Personal Hygiene Mentruasi. Jurnal Ilmu Kesehatan Masyarakat, 5(1), 15-23. JOUR

Ranjabir.k,. Kanwaljit,k,. \& Rajinder,. (2018) Menstrual Hygiene, Management, and Waste Disposal: $\quad$ Practicesand Challenges Faced by Girls/Women of Developing Countries, India Journal of Environmental and Public Health.

UNICEF. (2015). Water sanitation and hygiene in primary asian countries realities and recommendation.

USAID. (2013). Understanding and managing menstruation.
UKAID. (2014). Menstruation hygiene management for schoolgirls. India: Author 